\title{
Kondisi Sarana Air Bersih, Perilaku Hidup Bersih dan Sehat Terhadap Frambusia pada Anak-anak
}

\author{
Condition of Clean Water Sources and Personal Hygiene and Healthy \\ Behavior are Risk Factors of Frambusia among Children
}

\author{
Wanti, Enni Rosida Sinaga, Irfan, Mitrawati Ganggar
}

\section{Politeknik Kesehatan Kementerian Kesehatan Kupang}

\begin{abstract}
Abstrak
Kasus frambusia yang tercatat di Puskesmas Bondo Kodi Kabupaten Sumba Barat Daya, Nusa Tenggara Timur (NTT) terus meningkat dari 174 kasus tahun 2009 menjadi 327 kasus pada tahun 2010 dan 369 kasus pada tahun 2011. Pada tahun 2012, frambusia tertinggi terjadi di Desa Mali Iha di Kecamatan Bondo Kodi dengan 43 kasus. Penelitian ini bertujuan untuk mengetahui faktor-faktor lingkungan, perilaku, dan pengetahuan masyarakat yang berhubungan dengan kejadian penyakit frambusia pada anakanak. Penelitian observasional ini menggunakan rancangan studi kasuskontrol, dengan kondisi sarana air bersih (SAB), perilaku hidup bersih dan sehat (PHBS), dan pengetahuan masyarakat tentang frambusia sebagai variabel bebas. Sampel penelitian adalah 30 orang anak yang menderita frambusia (kasus) dan 30 orang anak sehat (kontrol) yang diambil dengan metode purposive sampling. Data dan informasi mengenai $S A B$, praktik PHBS, dan pengetahuan masyarakat tentang frambusia didapatkan dengan observasi dan wawancara, kemudian dianalisis dengan uji kai kuadrat. Ditemukan, secara statistik kejadian frambusia berhubungan bermakna dengan kondisi SAB (OR $=15,16$ dan nilai $p=0,035)$ dan PHBS $(O R=7$ dan nilai $p=0,048)$, tetapi tidak berhubungan dengan pengetahuan masyarakat tentang frambusia (nilai $p=0,283$ ). Penelitian ini menyimpulkan bahwa kondisi SAB dan PHBS merupakan faktor risiko frambusia.

Kata kunci: Frambusia, pengetahuan, perilaku hidup bersih dan sehat, sarana air bersih
\end{abstract}

\section{Abstract}

Frambusia cases recorded at Bondo Kodi Primary Health Care in Sumba Barat Daya District, East Nusa Tenggara (NTT) were continously increasing from 174 in 2009 to 327 in 2010 and 369 in 2011. In 2012, the highest frambusia occurred in Mali Iha Village with 43 cases. The present research was to define environmental, behavioural, and knowledge factors associated with the frambusia in children. This observational study employed casecontrol design with condition of clean water source, practices of personal hy- giene and health behavior, and community knowledge about frambusia as independent variables. Samples were 30 children with frambusia (cases) and 30 healthy children (control) who were selected using purposive sampling. Data and information on environmental condition, behavioral practices, and community knowledge were collected by interview and direct observation and were analyzed using chi-square test. It was found that statistically the frambusia cases were associated significantly with the condition of clean water source $(O R=15.16$, $p$ value $=0.035)$ and personal hygiene and healthy behavior $(O R=7, p$ value $=0.048)$, but were not associated with community knowledge ( $p$ value $=0.283$ ). It concludes that condition of clean water sources and personal hygiene and healthy behavior are risk factors of frambusia in children.

Keywords: Frambusia, knowledge, personal hygiene and healthy behavior, clean water source

\section{Pendahuluan}

Frambusia adalah penyakit menular menahun dan kambuh-kambuhan yang disebabkan oleh kuman Treponema pallidum subspesies pertenue. Frambusia umumnya menyerang anak berusia di bawah 15 tahun yang jika tidak diobati akan menyebabkan kecacatan. ${ }^{1}$ Pengobatan penyakit frambusia sangat mudah, yaitu dengan obat Benzathine Penicilline sekali suntik yang dapat menyembuhkan luka-luka akibat penyakit ini. ${ }^{2-4} \mathrm{Di}$ beberapa daerah masih ada anggapan bahwa frambusia merupakan penyakit biasa karena sifatnya yang tidak menimbulkan rasa sakit pada penderita. 1,5

Menurut World Health Organization (WHO), fram-

Alamat Korespondensi: Wanti, Politeknik Kesehatan Kementerian Kesehatan Kupang, Jl. Piet A. Tallo Kupang Nusa Tenggara Timur, Hp. 081338078478,

e-mail:trivena78@yahoo.com 
busia termasuk penyakit tropis yang terabaikan (neglected tropical disease). Indonesia merupakan penyumbang kasus frambusia terbesar di Asia Tenggara selain India dan Timor Leste. ${ }^{6}$ Di Indonesia, sampai tahun 2009 masih ada 8.309 kasus frambusia yang menginfeksi di 18 dari 33 provinsi, lima provinsi di antaranya termasuk kategori prevalensi tinggi. ${ }^{7}$ Frambusia merupakan indikator keterbelakangan suatu negara. ${ }^{8}$

Sampai saat ini, frambusia masih belum dapat dieliminasi dari seluruh wilayah Indonesia. Meskipun secara nasional angka prevalensinya sudah kurang dari 1 per 10.000 penduduk, beberapa provinsi masih memiliki prevalensi yang cukup tinggi, antara lain Nusa Tenggara Timur (NTT), Sulawesi Tenggara, Papua, Aceh, Jambi, Maluku, dan Maluku Utara.5,8 Telah diketahui bahwa perilaku, khususnya aktivitas mandi, merupakan faktor risiko frambusia. Penyakit ini sangat terkait dengan kondisi rumah, perilaku, dan sosial ekonomi. Tingkat sosialekonomi rendah, hunian yang padat, dan kebiasaan bergantian pakaian juga memengaruhi kejadian penyakit ini. ${ }^{9}$ Di Bondo Kodi, Kabupaten Sumba Barat Daya, frambusia meningkat terus dari 174 kasus tahun 2009 menjadi 327 kasus pada tahun 2010 dan 369 kasus pada tahun 2011. Pada tahun 2011 ini, jumlah frambusia tertinggi (43 kasus) terjadi di Desa Mali Iha yang berada di wilayah kerja Puskesmas Bondo Kodi Kabupaten Sumba Barat Daya. ${ }^{10}$

Frambusia merupakan salah satu dari kelompok penyakit yang menyebar tanpa hospes tetapi terjadi secara kontak langsung. Upaya pemberantasan frambusia dapat berhasil dengan baik apabila epidemiologi penyakit ini diketahui terlebih dahulu. Dengan memelajari epidemiologi frambusia, dapat ditentukan suatu metode atau teknologi yang efektif dalam upaya pemberantasan penyakit tersebut. Memberantas suatu penyakit memerlukan pengetahuan tentang cara penularan, perjalanan, gejala, diagnosis, pengobatan, dan pencegahan penyakit itu. ${ }^{10}$

Upaya pencegahan sekaligus pemberantasan penyakit menular seperti frambusia dapat dilakukan bila faktor-faktor yang berhubungan dengan kejadian penyakit tersebut diketahui sehingga pencegahan dapat dilakukan dengan lebih efektif dan efisien. Atas dasar ini, telah dilakukan penelitian epidemiologi frambusia di Desa Mali Iha, Bondo Kodi, Kabupaten Sumba Barat Daya. Penelitian ini bertujuan untuk mengetahui faktorfaktor perilaku dan lingkungan yang berhubungan dengan kejadian frambusia. Penelitian ini diharapkan dapat memberikan masukan kepada masyarakat, puskesmas, dan Dinas Kesehatan untuk mencegah dan mengobati penyakit frambusia.

\section{Metode}

Penelitian ini menerapkan metode observasional analitik dengan rancangan studi kasus-kontrol yang menga- mati status pajanan kelompok yang sakit (kasus) dibandingkan dengan kelompok yang tidak sakit (kontrol), dengan kejadian frambusia sebagai variabel bebas dan kondisi sarana air bersih (SAB), perilaku hidup bersih dan sehat (PHBS) masyarakat, dan pengetahuan masyarakat tentang frambusia sebagai variabel terikat. ${ }^{11}$

Sampel kasus berjumlah 30 orang anak usia $<15$ tahun penderita frambusia yang diambil secara purposive sampling dari total 43 penderita frambusia. Sampel kontrol adalah 30 orang anak usia $<15$ tahun yang tidak menderita frambusia. Kriteria inklusi kontrol adalah anak kontak serumah, kontak sepermainan, atau kontak sekolah yang tidak menderita frambusia.

Data primer tentang sarana air bersih (SAB), perilaku hidup bersih dan sehat (PHBS) masyarakat, dan pengetahuan masyarakat tentang frambusia diperoleh secara langsung dengan wawancara menggunakan kuesioner dan observasi menggunakan daftar tilik (checklist). Kondisi $\mathrm{SAB}, \mathrm{PHBS}$, dan pengetahuan tentang frambusia dikategorikan menjadi kurang (bila jawaban benar $<56 \%$ ) dan baik (bila jawaban benar $\geq 56 \%$ ). Data yang terkumpul kemudian dianalisis dengan uji kai kuadrat untuk menguji apakah variabel bebas berhubungan dengan variabel terikat.

\section{Hasil}

Frambusia merupakan penyakit menular yang masih merupakan masalah kesehatan masyarakat di Kabupaten Sumba Barat Daya khususnya di Kecamatan Kodi Desa Mali Iha. Tahun 2011 jumlah penderita frambusia masih tinggi yaitu sebanyak 43 kasus, seperti yang ditunjukkan dalam Tabel 1.

Tabel 1 menunjukkan bahwa paling banyak kasus frambusia pada golongan umur $6-15$ tahun atau anak usia sekolah dan yang paling sedikit adalah kelompok umur $0-5$ tahun.

\section{Kondisi Sarana Air Bersih}

Tabel 2 menunjukkan bahwa pada kelompok kasus kondisi SAB lebih banyak yang kurang baik dibandingkan pada kelompok kontrol. Dari hasil uji kai kuadrat didapatkan nilai p sebesar 0,035, yang artinya Ho ditolak atau ada hubungan antara kondisi sarana air bersih dengan kejadian penyakit frambusia. Nilai OR didapatkan 15,16 yang berarti mereka yang memiliki SAB dengan

Tabel 1. Jumlah Kasus Frambusia Menurut Golongan Usia

\begin{tabular}{lll}
\hline Golongan Usia & $\mathbf{n}$ & $\%$ \\
\hline $0-5$ tahun & 10 & 23 \\
$6-15$ tahun & 26 & 61 \\
$>16$ tahun & 7 & 16 \\
\hline Total & $\mathbf{4 3}$ & $\mathbf{1 0 0}$ \\
\hline
\end{tabular}


Tabel 2. Hubungan Sarana Air Bersih, Perilaku Hidup Bersih dan Sehat, dan Pengetahuan Tentang Frambusia dengan Kejadian Frambusia

\begin{tabular}{|c|c|c|c|c|c|c|c|c|c|}
\hline \multirow{2}{*}{ Variabel } & \multirow{2}{*}{ Kategori } & \multicolumn{2}{|c|}{ Kasus } & \multicolumn{2}{|c|}{ Kontrol } & \multicolumn{2}{|c|}{ Total } & \multirow{2}{*}{ Nilai $p$} & \multirow{2}{*}{ OR } \\
\hline & & $\mathbf{n}$ & $\%$ & $\mathbf{n}$ & $\%$ & $\mathbf{n}$ & $\%$ & & \\
\hline \multirow[t]{2}{*}{ Kondisi sarana air bersih } & Kurang & 26 & 87 & 9 & 30 & 35 & 58 & \multirow[t]{2}{*}{0,035} & \multirow[t]{2}{*}{15,2} \\
\hline & Baik & 4 & 13 & 21 & 70 & 25 & 42 & & \\
\hline \multirow[t]{2}{*}{ Perilaku hidup bersih dan sehat } & Kurang & 21 & 70 & 7 & 23 & 28 & 47 & \multirow[t]{2}{*}{0,048} & \multirow[t]{2}{*}{7} \\
\hline & Baik & 9 & 30 & 23 & 77 & 32 & 53 & & \\
\hline \multirow[t]{2}{*}{ Pengetahuan tentang frambusia } & Kurang & 26 & 87 & 3 & 10 & 29 & 48 & \multirow[t]{2}{*}{0,283} & \multirow[t]{2}{*}{56,3} \\
\hline & Baik & 4 & 13 & 27 & 90 & 31 & 52 & & \\
\hline
\end{tabular}

kondisi yang kurang baik mempunyai risiko untuk terkena frambusia sebesar 15,16 kali dibandingkan mereka yang memiliki SAB dengan kondisi yang baik.

\section{Perilaku Hidup Bersih dan Sehat (PHBS)}

Tabel 2 juga menunjukkan bahwa PHBS pada kelompok kasus lebih banyak yang kurang dibandingkan PHBS pada kelompok kontrol. Hasil uji kai kuadrat didapatkan nilai $\mathrm{p}<0,05$, yang artinya terdapat hubungan antara perilaku hidup bersih dan sehat dari masyarakat dengan kejadian penyakit frambusia. Hasil perhitungan OR didapatkan nilai 7 yang artinya mereka yang mempunyai PHBS kurang mempunyai risiko terkena frambusia 7 kali lebih besar dibandingkan mereka yang mempunyai PHBS yang baik.

\section{Pengetahuan Masyarakat Tentang Frambusia}

Berdasarkan Tabel 2 diketahui bahwa pengetahuan tentang frambusia pada kelompok kasus sebagian besar masih kurang, sedangkan pada kelompok kontrol sudah baik. Hasil uji kai kuadrat didapatkan nilai $p>0,05$ yang berarti tidak ada hubungan pengetahun tentang frambusia dengan kejadian penyakit frambusia.

\section{Pembahasan}

Penelitian ini menemukan bahwa lebih dari separuh kasus frambusia terjadi pada anak-anak berusia 6 sampai 15 tahun yaitu $61 \%$ diikuti berikutnya anak berusia 0 5 tahun yaitu $16 \%$. Temuan ini tidak jauh berbeda dengan penelitian sebelumnya bahwa penyakit ini biasanya menyerang pada anak-anak berusia di bawah 15 tahun, yaitu usia taman kanak-kanak dan usia sekolah (6 - 10 tahun) dan jika tidak diobati dapat menimbulkan kecacatan. ${ }^{5,12} \mathrm{Hal}$ ini juga sama dengan penelitian sebelumnya di Jayapura, bahwa kasus frambusia pada kelompok umur $<5$ tahun hanya ditemukan $14 \% .{ }^{9}$ Meskipun frambusia banyak ditemukan pada usia $<15$ tahun, menurut WHO usia yang paling rentan terinfeksi frambusia adalah 2 sampai 5 tahun. ${ }^{13}$ Namun, hal sebaliknya ditemukan di Kongo, penderita frambusia yang berumur < 15 tahun hanya $37,6 \%$ dan selebihnya adalah pada usia $>15$ tahun. ${ }^{14}$ Penelitian di Desa Mali Iha ini menemukan bahwa bagian tubuh yang terkena penyakit frambusia, antara lain sekitar lutut, sekitar siku, betis, punggung, dan muka. Sesuai teori, inflamasi pada frambusia ditandai dengan macupapular merah di seluruh tubuh termasuk di tangan, kaki, ketiak, mulut, dan anogenital. ${ }^{5}$

\section{Kondisi Sarana Air Bersih}

Hasil penelitian ini menunjukkan bahwa mereka yang mempunyai kondisi SAB kurang baik mempunyai risiko terkena frambusia 15,2 kali dibandingkan dengan mereka yang memiliki kondisi SAB baik. Pada kelompok kasus, sebagian besar $(87 \%)$ responden memiliki kondisi $\mathrm{SAB}$ masih berkategori kurang (tidak tersedia ledeng atau PDAM). Pada kelompok ini, sebagian besar masyarakat mengambil air untuk keperluan minum dan memasak dari sungai dan mata air yang jaraknya sangat jauh $(2-4 \mathrm{~km})$ dari rumah mereka. Sebenarnya, mereka dapat membeli air bersih dari kran umum, tetapi ini hanya terbatas dilakukan oleh masyarakat yang secara ekonomi mampu. Namun, mereka yang mampu membeli pun sebagian besar hanya menggunakan air bersih untuk memasak dan minum, sedangkan untuk keperluan seharihari lainnya seperti mandi dan mencuci baju masih untuk mengambil air dari kali dan sungai walaupun jaraknya jauh dan airnya kurang bersih.

Hal ini berbeda dengan kondisi SAB pada kelompok kontrol. Lebih dari separuh masyarakat mempunyai kondisi SAB baik (memiliki saluran ledeng/PDAM) untuk keperluan minum, memasak, mandi, dan cuci pakaian. Pada kelompok ini, mereka yang tidak memiliki saluran ledeng/PDAM biasa membeli air bersih dari kran umum. Selain itu, jumlah air bersih pada kelompok ini tersedia dengan cukup. Jadi, pada kelompok kontrol air bersih tersedia dengan kualitas yang baik dan jumlah yang cukup.

Berdasarkan pengamatan secara langsung pada sumber air yang digunakan oleh masyarakat di Desa Mali Iha khususnya yang bersumber dari sungai atau kali, secara fisik air tersebut tidak memenuhi syarat karena sangat keruh dan berwarna kecoklatan yang tidak layak untuk dipakai untuk keperluan sehari-hari, apalagi dikonsumsi. Dengan kondisi fisik air seperti ini, sangat memungkin- 
kan kasus frambusia meningkat. Pada kelompok kasus, selain kondisi sarana dan kualitas air bersih tidak memenuhi syarat, secara kuantitas juga kurang karena untuk mengambil air mereka harus berjalan jauh dengan hanya mampu membawa beberapa jeriken (kurang lebih 5 liter untuk sekali jalan). Akibatnya, mereka terpaksa memakai air yang tidak bersih tersebut untuk memenuhi kebutuhan sehari-hari. Selain itu, sumber air mereka (air kali) juga digunakan untuk memandikan hewan ternak sehingga air kali tersebut dapat tercemar yang yang menimbulkan gangguan kesehatan termasuk penyakit kulit, terutama bila airnya tidak dimasak terlebih dahulu.

Bulan April hingga September merupakan musim kemarau ketika curah hujan rendah sehingga persediaan air bersih sangat terbatas. Ini merupakan kemungkinan jawaban, mengapa selama bulan April hingga September kasus frambusia relatif tinggi $(9-16 \%)$. Oktober hingga Maret merupakan musim penghujan sehingga curah hujan tinggi dan ketersediaan air lebih tinggi dibandingkan musim kemarau, hal ini juga diikuti oleh turunnya kasus frambusia $(0-4 \%) .{ }^{15}$ Namun, pada musim ini kasus frambusia masih ada. Walaupun air untuk keperluan sehari-hari yang tersedia yang lebih banyak, belum tentu kualitasnya memenuhi syarat-syarat kesehatan.

Kebanyakan air kali dan mata air masih diragukan kebersihannya dan tidak diketahui kualitasnya. ${ }^{15}$ Pada penelitian yang dilakukan di Kota Jayapura, ditemukan bahwa rumah dengan ketersediaan air bersih yang kurang menyebabkan penghuninya memiliki risiko terkena frambusia 5,40 kali dibandingkan rumah dengan ketersediaan air yang cukup. ${ }^{9}$ Ketersediaan air bersih yang kurang baik karena terbatasnya sarana air bersih yang tersedia maupun terbatasnya kuantitas air bersih itu sendiri dapat menyebabkan penghuninya tidak dapat melakukan aktivitasnya sehari-hari dengan baik seperti minum, mandi, dan mencuci. ${ }^{9}$

\section{Perilaku Hidup Bersih dan Sehat Masyarakat}

Hasil penelitian ini menunjukkan bahwa ada hubungan PHBS masyarakat dengan kejadian frambusia. Dengan nilai OR sebesar 7, artinya mereka yang mempunyai PHBS kurang mempunyai risiko terkena frambusia 7 kali dibandingkan dengan mereka yang mempunyai PHBS baik. Hal ini sesuai dengan pengamatan, bahwa perilaku masyarakat dalam menjaga diri masih sangat kurang, antara lain jarang mandi dan kalaupun mandi jarang menggunakan sabun, jarang mencuci tangan, jarang keramas, jarang memotong kuku, jarang mengganti dan mencuci pakaian, setelah mandi tidak mengeringkan badan dengan handuk, dan masih ada yang menggunakan pakaian secara bergantian dengan anggota keluarga lainnya. Hal ini juga ditunjukkan oleh penampilan anak-anak maupun orang dewasa yang dalam kesehariannya mereka jarang memakai sandal, baju yang mereka pakai sangat kotor, badan terlihat kotor termasuk kuku dan jari-jari tangan dan kaki. Status higiene perorangan dan lingkungan yang kurang baik serta kurangnya pengetahuan tentang kebersihan diri dapat dijadikan sebagai faktor-faktor yang berhubungan dengan kejadian frambusia. ${ }^{9,10} \mathrm{Hal}$ ini juga sesuai dengan kesimpulan pertemuan internasional dalam eradikasi penyakit bahwa frambusia ditularkan secara langsung kontak kulit dengan kulit di antara orang-orang dengan higiene perorangan yang jelek. ${ }^{2}$

Dengan PHBS yang masih kurang baik akan memudahkan penularan Treponema palidum, kuman penyebab frambusia. Penularan frambusia pada umumnya terjadi karena kontak langsung dengan penderita. Selain itu, frambusia juga dapat ditularkan secara tidak langsung, yaitu kontak dengan benda-benda yang sudah terkontaminasi oleh cairan dari luka penderita frambusia. ${ }^{16}$ Adanya hubungan PHBS yang kurang dengan kejadian frambusia dapat dijelaskan dengan kecukupan dan kualitas air yang masih rendah sehingga tidak mencukupi untuk membersihkan luka-luka di tubuh, termasuk membersihkan barang-barang yang terkontaminasi dengan cairan dari luka pasien frambusia. Hal itu juga didukung oleh kebiasaan masyarakat yang jarang memakai sabun, jarang mandi, jarang mengganti dan mencuci baju sehingga bila orang sehat kontak dengan penderita frambusia seperti teman sekolah, teman bermain, dan anggota keluarganya akan dengan mudah tertular meskipun kontaknya tidak langsung seperti melalui kebiasaan pemakaian bersama handuk dan pakaian yang belum didesinfeksi sebelumnya. Penggunaan air dan sabun yang cukup serta menjaga kebersihan perorangan dapat mengurangi angka kejadian penyakit. ${ }^{17}$

Faktor risiko frambusia tidak bersifat tunggal, tetapi banyak dan saling terkait. Faktor-faktor risiko yang saling berkaitan yang telah diketahui adalah kondisi rumah, status sosial-ekonomi, dan perilaku termasuk perilaku berganti pakaian. ${ }^{18}$ Penelitian di Jayapura mendukung temuan ini, bahwa mereka yang jarang mandi mempunyai risiko terinfeksi frambusia 3,69 kali dibandingkan dengan mereka yang rajin mandi. Dibandingkan dengan kebiasaan mandi, perilaku jarang berganti pakaian atau handuk mempunyai risiko terinfeksi frambusia 1,54 kali daripada mereka yang rajin berganti pakaian atau handuk, walaupun secara statistik risiko ini tidak bermakna. ${ }^{5}$ Temuan ini mengukuhkan penelitian sebelumnya di tiga Desa Kecamatan Nggaha Ori Angu Sumba Timur. Ditemukan bahwa kejadian frambusia berhubungan kebersihan lingkungan (nilai $\mathrm{p}=0,024$ ) dan kebersihan perorangan (nilai $\mathrm{p}=0,003$ ). 19

Keadaan tersebut berbeda dengan PHBS pada kelompok kontrol. Sebagian besar kelompok kontrol masih menjaga kebersihan diri dengan mandi dua kali sehari. Pada kelompok ini, sebagian besar masyarakat selalu 
menyediakan air bersih yang cukup untuk keperluan mandi, menggunakan sabun pada saat mandi, pakaian yang digunakan sering diganti dua kali sehari, memahami pentingnya menjaga kebersihan perorangan, dan setelah mandi menggunakan handuk atau kain untuk mengeringkan badan.

Mobilisasi penduduk yang tinggi merupakan salah satu faktor yang memengaruhi kejadian frambusia di suatu daerah. ${ }^{19}$ Anak-anak, yang sebagian besar terinfeksi, umumnya mempunyai mobilitas tinggi, baik karena bersekolah maupun karena bermain di tetangganya sehingga ada kemungkinan kontak dan menularkan frambusia kepada orang lain selain anggota keluarganya. Aksesibilitas agent menginfeksi host serta pencemaran lingkungan yang cukup tinggi juga didukung oleh kemampuan mikroba patogen ini untuk mengubah sifat dirinya dari waktu ke waktu, misalnya melakukan mutasi yang menimbulkan perubahan sifat dan resistensi terhadap obat-obatan. ${ }^{20}$

\section{Pengetahuan Masyarakat Tentang Frambusia}

Penelitian ini menemukan bahwa tidak ada hubungan pengetahuan masyarakat tentang frambusia dengan kejadian penyakit frambusia. Pengetahuan masyarakat tentang penyakit frambusia pada kelompok kasus masih sangat kurang karena ada anggapan yang salah bahwa penyakit frambusia, atau masyarakat setempat menyebutnya dengan Ndawa, merupakan hal yang biasa karena penyakit ini tidak menimbulkan rasa sakit. Pada kelompok kasus, sebagian besar masyarakat tidak tahu gejala, cara penularan, dan cara pencegahan frambusia. Hal ini berbeda dengan kondisi kelompok kontrol yang sebagian besar masih mengerti tentang penyakit frambusia atau Ndawa serta gejala, pengobatan, dan faktor yang memengaruhi kejadian frambusia. Meskipun dalam penelitian ini secara statistik pengetahuan tidak mempunyai hubungan yang bermakna dengan kejadian frambusia, penelitian di Jayapura menyatakan bahwa tingkat pengetahuan orang tua yang kurang, anak-anak mereka berisiko 2,17 kali menderita frambusia dibandingkan dengan pengetahuan orang tua mereka yang baik. ${ }^{9}$

Dalam penelitian ini, rendahnya pengetahuan masyarakat tentang frambusia mungkin disebabkan oleh tingkat pendidikan yang rendah, akses informasi yang kurang, dan akses pelayanan kesehatan yang sulit karena lokasinya jauh dan sulit dijangkau dari puskesmas. Pengetahuan tentang frambusia yang rendah akan mengakibatkan pula kebersihan diri dan lingkungan sekitar menjadi buruk. Di Afrika, Asia, dan Amerika Selatan, frambusia terutama terjadi pada populasi yang miskin, tinggal di perdesaan, terpinggirkan atau terpencil, penduduknya padat, air bersih kurang tersedia, serta sanitasi dan higiene perorangan yang rendah. ${ }^{16}$

Keberadaan daerah kantong yang terletak di pedalam- an yang sulit dijangkau pelayanan kesehatan dan kondisi lingkungan yang buruk menyebabkan penurunan prevalensi frambusia berjalan lambat. ${ }^{8}$ Keadaan ini memerlukan prasarana dan sarana untuk meningkatkan akses masyarakat ke pelayanan kesehatan seperti kendaraaan operasional, tenaga kesehatan yang jumlahnya cukup dan siap menjangkau lokasi kasus, penyediaan obat yang mencukupi, dan pengobatan yang tuntas kepada semua penderita frambusia. Tantangan eradikasi frambusia sekarang adalah bahwa pemberantasan frambusia bukan program utama dalam program nasional kesehatan, akses masyarakat di daerah terpencil ke pelayanan kesehatan, dan resistensi frambusia terhadap penisilin. ${ }^{1}$ Sekitar $10 \%$ kasus frambusia dapat menyebabkan ketidakmampuan dan kecacatan organ sekitar sehingga pengobatan penderita frambusia sampai sembuh sangat penting. ${ }^{3}$

\section{Kesimpulan}

Penelitian ini menyimpulkan bahwa kondisi SAB dan PHBS masyarakat yang kurang berhubungan secara bermakna dengan kejadian penyakit frambusia pada anakanak. Namun, pengetahuan masyarakat yang kurang tentang epidemiologi frambusia terbukti tidak berhubungan secara bermakna dengan kejadian frambusia.

\section{Saran}

Dinas kesehatan/puskesmas diharapkan dapat bekerja sama dengan Dinas Pendidikan, Pemuda, dan Olahraga (PPO) untuk memberikan penyuluhan tentang frambusia, menyediakan sarana air bersih, meningkatkan penemuan penderita dan yang kontak dengan penderita secara aktif, dan mengobati penderita sampai tuntas. Masyarakat diharapkan meningkatkan PHBS, seperti mandi dua kali sehari dengan memakai sabun, tidak tukar-menukar dalam berpakaian atau handuk, dan selalu memakai air bersih untuk keperluan mandi dan mencuci. Bila masyarakat terinfeksi frambusia segera berobat ke sarana pelayanan kesehatan sampai sembuh.

\section{Daftar Pustaka}

1. Asiedu K, Amouzou B, Dhariwal A, Karam M, Lobo D, Patnaikf S, et al. Yaws eradication: past efforts and future perspectives. Bulletin of the World Health Organization. 2008; 86(7): 499.

2. Maurice J. WHO plans new yaws eradication campaign. Lancet. 2012; 379: 1377-8.

3. The Carter Center. Summary of the twentieth meeting of the international task force for disease eradication (II). 2012 [cited Jan 24 2012]. Available from: http://www.cartercenter.org/resources/pdfs/news/health_publications/itfde/ITFDE-summary-112712.pdf].

4. Rinaldi A. Yaws eradication: facing old problem, raising new hopes. Plos Neglected Tropical Diseases. 2012; e1837.

5. Departemen Kesehatan Republik Indonesia. Pedoman pemberantasan penyakit frambusia. Jakarta: Departemen Kesehatan Republik 
Indonesia; 2005.

6. World Health Organization. Regional strategy on eradication of yaws 2006-2010. Geneva: World Health Organization; 2006.

7. Ministry of Health. Current situation of yaws in Indonesia: report from the ministry of health. Jakarta: Ministry of Health Republic of Indonesia; 2009.

8. Departemen Kesehatan Republik Indonesia. Profil kesehatan Indonesia 2006. Jakarta: Departemen Kesehatan Republik Indonesia; 2007.

9. Boedisusanto RI, Waskito F, Kushadiwijaya H. Analisis kondisi rumah, sosial dan perilaku sebagai faktor risiko kejadian frambusia di Kota Jayapura tahun 2007. Berita Kedokteran Masyarakat. 2009; 25(2): 82-7.

10. Dinas Kesehatan Kabupaten Sumba Barat Daya. Laporan tahunan Kabupaten Sumba Barat Daya. Sumba Barat Daya: Dinas Kesehatan Kabupaten Sumba Barat Daya; 2012.

11. Departemen Kesehatan Republik Indonesia. Pemberantasan penyakit menular dan penyehatan lingkungan penyakit frambusia. Jakarta: Departemen Kesehatan Republik Indonesia; 1991.

12. Notoatmodjo S. Ilmu kesehatan masyarakat. Jakarta: Rineka Cipta; 2002.

13. Rinaldi A. Yaws: a second (and maybe last?) chance for eradication. PLoS Negl Trop Dis [serial on interrnet]. 2008; 2(8): e275[cited 2013 March 4]. Available from: www.plosntds.org/article/info\%3Adoi \%2F10.13771\%2Fjournal.pntd.0000275.

14. Annonymous. Elimination of yaws in India. Weekly Epidemiological
Record. 2008; 83(15): 125-32.

15. Sersti, Kiwila G, Dhorda M, Lonlas S, Myatt M, Ilunga BK, et al. Prevalence study of yaws in the Democratic Republic of Congo using the lot quality assurance sampling method. PloS Negl Trop Dis [serial on internet]. 2009; 4(7): 1-9 [cited 2013 Jan 5]. Available from: www.plosone.org/article/info\%3Adoi\%2F10.1371\%Fjournal.pone.000 6338.

16. BPS Provinsi Nusa Tenggara Timur. Nusa Tenggara Timur dalam angka 2011. Kupang: Badan Pusat Statistik; 2012.

17. Amin R, Basher A, Zaman F, Faiz MA. Global eradication of yaws: neglected disease with research priority. Journal of Medicine. 2009; 10: 109-14.

18. Kandun IN, ed. Manual pemberantasan penyakit menular. Jakarta: xxx; 2000.

19. Sehgal VN, Jain S, Bhattacharya SN, Thappa DM. Yaws control/e radication. International Journal of Dermatology. 1994; 33(1): 16-20.

20. Entjang I. Ilmu kesehatan masyarakat. Bandung: PT Citra Aditya Bakti; 2000.

21. Liunokas. Faktor-faktor yang mempengaruhi kejadian frambusia pada anak di Desa Makamenggit Tanatuku Praikarang Kecamatan Nggaha Ori Angu Kabupaten Sumba Timur Nusa Tenggara Timur [tesis]. Yogyakarta: Universitas Gadjah Mada; 2009.

22. Hamzah H. Manajemen penyakit berbasis wilayah. Jurnal Manajemen Pelayanan Kesehatan. 2008; 2: 72-6. 